\title{
Disintegration and Rupture Testing of Omega-3 Soft Capsules
}

Nasser N. Nyamweya ${ }^{1 *}$ and Teddy M. Mochama ${ }^{1}$

${ }^{1}$ Department of Pharmaceutics and Pharmacy Practice, School of Pharmacy, College of Health Sciences, University of Nairobi, Nairobi, Kenya.

e-mail: nasser04@yahoo.com

\section{ABSTRACT}

Omega-3 fatty acid soft capsules are a popular nutritional supplement. Previous product quality studies reported in the literature have mostly only addressed specifications for omega-3 fatty acid content and chemical stability aspects. This study aimed to characterize the in vitro release characteristics of omega-3 from soft capsules in aqueous media using disintegration and rupture tests. Four gelatin and one non-gelatin (starch/carrageen) commercially available omega-3 soft capsule products were evaluated using water and $0.1 \mathrm{~N} \mathrm{HCl}$ as the media. In general, most products displayed faster release in the acidic medium compared to water. There was a statistically significant correlation between the disintegration and rupture test times. Although between-product disintegration and rupture test times varied considerably, all products ruptured within 15 minutes and completely disintegrated within 30 minutes in both media.

KEYWORDS: Omega 3 fatty acid supplements, fish oil supplements, soft capsules, disintegration, rupture test

\section{INTRODUCTION}

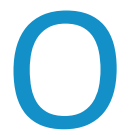

mega-3 fatty acids are essential for human health, with numerous studies investigating their benefits in cardiovascular disease and inflammation-mediated disorders. Recently an omega-3 derived product, Vascepa (Amarin Pharma) (an ester of the omega-3 fatty acid eicosapentaenoic acid), received U.S. Food and Drug Administration (FDA) approval as an adjunct therapy in the treatment of cardiovascular disease and lowering of triglyceride levels (1).

Fish oils are a major dietary source of omega-3 fatty acids. As oils, the most convenient dosage form for their oral administration is a soft capsule. Due to the high incidence of cardiovascular disease globally and concern about the role of inflammation in many other diseases, there is a large consumer demand for fish oil capsules as supplements to augment dietary omega- 3 fatty acid intake. Recent surveys in the United States have indicated that fish oil capsules were second only to multi-vitamin tablets as the most popular supplements, being taken by $33 \%$ of nutritional supplement users (2).

It is well established that the ability of a dosage form to release its active ingredients in the gastrointestinal tract is a prerequisite for oral absorption. Given the regulatory differences between the pharmaceutical and nutritional supplement industries, the tests typically conducted to characterize release of the active ingredient from the dosage form for pharmaceuticals are not given the same level of attention for nutraceuticals. The prior work reported in the literature has focused almost entirely on assessing the label claim and oxidative quality of omega-3 capsules (3-5). Very little work has been published on the disintegration and dissolution characteristics of these products. Scattergood reported on the disintegration of delayed-release coated fish oil soft gel capsules (6). Two studies have investigated the release characteristics of (non-fish oil) soft gelatin capsules by disintegration and rupture tests $(7,8)$. Therefore, this work aimed to evaluate the disintegration and rupture test characteristics of omega-3 fish oil capsules.

\section{MATERIALS AND METHODS}

Five different brands of commercially available fish oil soft capsules were procured from local retailers. The product names, active ingredients, manufacturers, and expiration dates are shown in Table 1 . Any additional ingredients listed on the product labels are also shown in Table 1. One product (Seven Seas) was a non-gelatin shell soft capsule, and the others were gelatin-based capsules.

* Corresponding author. 
Table 1. List of Products Studied

\begin{tabular}{|c|c|c|c|c|c|}
\hline $\begin{array}{l}\text { Brand Name } \\
\text { (Generic Name) }\end{array}$ & Omega 3 Fatty Acids and Other Ingredients from Label & Manufacturer Name and Location & $\begin{array}{l}\text { Batch/Lot } \\
\text { Number }\end{array}$ & $\begin{array}{l}\text { Manf. } \\
\text { Date }\end{array}$ & $\begin{array}{l}\text { Expiry } \\
\text { Date }\end{array}$ \\
\hline $\begin{array}{l}\text { Seven Seas } \\
\text { (Cod Liver Oil } \\
\text { Plus Omega 3) }\end{array}$ & $\begin{array}{l}\text { Cod liver oil - } 268 \mathrm{mg} \\
\text { Fish oil - } 257 \mathrm{mg} \\
\text { Omega } 3 \text { nutrients: } 120 \mathrm{mg} \text { (EPA and DHA - } 85 \mathrm{mg} \text { ) } \\
\text { Other ingredients: Vit A - } 2666 \mathrm{IU} \text {; Vit D - } 100 \mathrm{IU} \text {; Vit E } \\
\text { (as dl-alpha tocopheryl acetate) } \\
\text { Capsule shell: modified maize starch, glycerol, } \\
\text { carrageenan (gelling agent), water, sodium carbonate }\end{array}$ & $\begin{array}{l}\text { Eurocaps, Gwent, UK (for Seven } \\
\text { Seas Limited, UK) }\end{array}$ & 103953 & May 2018 & May 2020 \\
\hline $\begin{array}{l}\text { Higher Nature } \\
\text { (Omega } 3 \text { Fish } \\
\text { Oil) }\end{array}$ & $\begin{array}{l}\text { Total fish oil } 1000 \mathrm{mg} \\
\text { EPA - } 180 \mathrm{mg} \\
\text { DHA - } 120 \mathrm{mg} \\
\text { Other ingredients: natural mixed tocopherols } \\
\text { Capsule shell: gelatin (bovine), glycerine, d-alpha } \\
\text { tocopherol }\end{array}$ & $\begin{array}{l}\text { Higher Nature, Burwash Common, } \\
\text { East Sussex, UK }\end{array}$ & QB139542/1 & N/A & Dec 2020 \\
\hline $\begin{array}{l}\text { Quest } \\
\text { (Omega } 3 \text { Fish } \\
\text { oil) }\end{array}$ & $\begin{array}{l}\text { Fish oil concentrate }-1000 \mathrm{mg} \\
\text { EPA - } 180 \mathrm{mg} \\
\text { DHA - } 120 \mathrm{mg} \\
\text { Other ingredients: only Vit E }-5 \mathrm{mg} \text { is listed }\end{array}$ & $\begin{array}{l}\text { Quest Vitamins Limited, Gooses } \\
\text { Foot Estate, Kingstone, Hereford, } \\
\text { UK }\end{array}$ & 18044 & N/A & Feb 2021 \\
\hline $\begin{array}{l}\text { Mydawa } \\
\text { (Omega } 3 \text { Fish } \\
\text { Oil Capsules) }\end{array}$ & $\begin{array}{l}\text { Fish oil }-1000 \mathrm{mg} \\
\text { EPA }-180 \mathrm{mg} \\
\text { DHA - } 120 \mathrm{mg} \\
\text { Other ingredients: not mentioned, but product is } \\
\text { referred to as a "soft gelatin capsule" }\end{array}$ & $\begin{array}{l}\text { Ocean Healthcare Pvt Ltd, } \\
\text { Tamilnadu, India }\end{array}$ & OHS18087 & Jul 2018 & Jul 2020 \\
\hline $\begin{array}{l}\text { Mega (Salmon } \\
\text { Oil) }\end{array}$ & $\begin{array}{l}\text { Natural salmon oil - } 1000 \mathrm{mg} \\
\text { EPA - } 180 \mathrm{mg} \\
\text { DHA - } 120 \mathrm{mg} \\
\text { Other ingredients: gelatin - } 272 \mathrm{mg} \text {, glycerol - } 120 \mathrm{mg} \text {, } \\
\text { d-alpha tocopherol - } 1.34 \mathrm{mg} \text {, water purified - } 34 \mathrm{mg}\end{array}$ & $\begin{array}{l}\text { Contract Manufacturing and } \\
\text { Packaging Services Pty Ltd., } \\
\text { Wetherill Park, NSW, Australia }\end{array}$ & 8659 & Feb 2019 & Feb 2022 \\
\hline
\end{tabular}

Manf - manufacture; EPA - eicosapentaenoic acid; DHA - docosahexaenoic acid, Vit - vitamin, UK - United Kingdom, N/A - not available.

\section{Methods}

Disintegration testing was performed using six capsules in a ZT3 disintegration testing machine (Erweka, Germany) fitted with a basket-rack assembly and set to operate at $37 \pm 0.5^{\circ} \mathrm{C}$. The disintegration media used were distilled water and $0.1 \mathrm{~N}$ hydrochloric acid ( $\mathrm{HCl})(1000 \mathrm{~mL}$ for each). The rupture test was performed as described in USP 42/ NF 37 chapter $<2040>$ for dietary supplements with USP apparatus 2 (paddles), operating at $50 \mathrm{rpm}$ at $37 \pm 0.5^{\circ} \mathrm{C}$, with $700 \mathrm{~mL}$ media volume (9). The media volume was selected to facilitate viewing of the released oil when the capsules ruptured. The capsules floated due to lower specific gravity of oil compared to water, so a stainlesssteel helix-type sinker was placed on each capsule before beginning the test.

\section{Statistical Analysis}

Descriptive statistics, t-tests (assuming unequal variances), and linear regression analysis were performed using Microsoft Excel. Analysis of variance (ANOVA) was performed using Real Statistics Resource Pack software (Release 6.8). ANOVA was used to determine whether there were significant differences between the different products in disintegration or rupture test times. The ANOVA requirement for homogeneity of variances was not met for most between-product comparisons (Levene's test, $p<0.05)$. Therefore, a one-way Welch's ANOVA test was used for the product comparisons with the GamesHowell post hoc test used for multiple comparisons. A $p$-value of 0.05 was used as the significance limit for all statistical tests.

\section{RESULTS}

The test results are shown in Table 2. The Seven Seas product had small size capsules with a mean weight of $581 \mathrm{mg}$, whereas the mean weight for the other four products ranged from 1300 to $1400 \mathrm{mg}$.

Disintegration times ranged from 5 to 25 minutes in water and 4 to 20 minutes in $0.1 \mathrm{~N} \mathrm{HCl}$. Rupture test times ranged from 2 to 14 minutes in water and 1 to 13 minutes in $0.1 \mathrm{~N} \mathrm{HCl}$. Table 3 shows the $p$-values for the effect of media on disintegration and rupture test times. All products showed significantly faster disintegration in the 
Table 2. Omega-3 Soft Gelatin Capsule Test Results

\begin{tabular}{|c|c|c|c|c|c|c|}
\hline Product & Weight (mg) & $\begin{array}{l}\text { Capsule Shape and } \\
\text { Length }(\mathrm{mm})\end{array}$ & $\begin{array}{c}\text { Disintegration } \\
\text { Time } \mathrm{H} 20 \text { (min:sec) }\end{array}$ & $\begin{array}{l}\text { Disintegration } \\
\text { Time } 0.1 \mathrm{~N} \mathrm{HCl} \\
\text { (min:sec) }\end{array}$ & $\begin{array}{l}\text { Rupture Test Time } \\
\text { H2O (min:sec) }\end{array}$ & $\begin{array}{l}\text { Rupture Test Time } \\
0.1 \mathrm{~N} \mathrm{HCl} \text { (min:sec) }\end{array}$ \\
\hline $\begin{array}{l}\text { Seven Seas } \\
(\operatorname{code}=a)\end{array}$ & $\begin{array}{c}581(14) \\
\text { bcde } \neq\end{array}$ & $\begin{array}{l}\text { Oval } \\
14.5\end{array}$ & $\begin{array}{c}4: 43(0: 02) \\
\text { bcde }\end{array}$ & $\begin{array}{c}3: 48(0: 13) \\
\text { bcde }\end{array}$ & $\begin{array}{c}1: 50(0: 35) \\
\text { bcd }\end{array}$ & $\begin{array}{c}\text { 1:07 (0:06) } \\
\text { bcde }\end{array}$ \\
\hline $\begin{array}{l}\text { Higher Nature } \\
(\text { code }=b)\end{array}$ & $\begin{array}{c}1282(10) \\
\text { acde } \neq\end{array}$ & $\begin{array}{l}\text { Oblong } \\
24.0\end{array}$ & $\begin{array}{c}6: 20(0: 05) \\
\text { acde }\end{array}$ & $\begin{array}{c}4: 46(0: 15) \\
\text { acd }\end{array}$ & $\begin{array}{c}9: 34(0: 15) \\
\text { ade }\end{array}$ & $\begin{array}{c}5: 29(2: 28) \\
\text { ade }\end{array}$ \\
\hline $\begin{array}{l}\text { Quest } \\
(\text { code }=c)\end{array}$ & $\begin{array}{c}1306(11) \\
\text { abde } \neq\end{array}$ & $\begin{array}{l}\text { Oblong } \\
25.7\end{array}$ & $\begin{array}{c}13: 47(2: 18) \\
\text { abde }\end{array}$ & $\begin{array}{l}12: 41(2: 45) \\
\text { abde }\end{array}$ & $\begin{array}{c}10: 20(0: 53) \\
\text { ade }\end{array}$ & $\begin{array}{c}8: 53(0: 53) \\
\text { ade }\end{array}$ \\
\hline $\begin{array}{l}\text { MyDawa } \\
(\text { code }=d)\end{array}$ & $\begin{array}{c}1334(13) \\
\text { abce } \neq\end{array}$ & $\begin{array}{l}\text { Oblong } \\
26.4\end{array}$ & $\begin{array}{l}24: 50(2: 58) \\
\text { abce }\end{array}$ & $\begin{array}{c}\text { 19:57 (0:59) } \\
\text { abce }\end{array}$ & $\begin{array}{c}\text { 14:14 }(0: 44) * \\
\text { abce }\end{array}$ & $\begin{array}{c}12: 48(2: 17)^{* *} \\
\text { abce }\end{array}$ \\
\hline $\begin{array}{l}\text { Mega } \\
(\operatorname{code}=e)\end{array}$ & $\begin{array}{l}1393(17) \\
\text { abcd } \neq\end{array}$ & $\begin{array}{l}\text { Oblong } \\
26.6\end{array}$ & $\begin{array}{c}9: 21(0: 03) \\
\quad \text { abcd }\end{array}$ & $\begin{array}{c}4: 37(0: 08) \\
\text { acd }\end{array}$ & $\begin{array}{c}2: 07(0: 10) \\
\text { bcd }\end{array}$ & $\begin{array}{l}0: 47(0: 09) \\
\quad \text { abcd }\end{array}$ \\
\hline $\begin{array}{l}\text { Welch's ANOVA F } \\
\text { value }\end{array}$ & $13,338^{\ddagger}$ & --- & 8705 & 341 & 1075 & 142 \\
\hline $\mathrm{df}_{1}, \mathrm{df}_{2}$ & 4,95 & & $4,11.6$ & $4,11.7$ & $4,11.6$ & $4,11.1$ \\
\hline$p$-value & $<0.0001$ & & $<0.0001$ & $<0.0001$ & $<0.0001$ & $<0.0001$ \\
\hline
\end{tabular}

Data are presented as mean values with SD in parentheses (weight, $n=20$; dimensions, $n=10$; disintegration, $n=6$; rupture test, $n=6$ ).

The letters $(a, b, c, d, e)$ represent capsules with significant differences compared to other products (based on Games-Howell post-hoc test).

* Standard ANOVA and Tukey's HSD post-hoc.

*one unit ruptured at 15:31 min; ** one unit ruptured at 16:29 min.

$D f$-degrees of freedom; ANOVA - one-way analysis of variance; HSD - honestly significant difference.

Table 3. Effect of Media (Water vs. $0.1 \mathrm{~N} \mathrm{HCl}$ ) on Disintegration

\begin{tabular}{|c|c|c|}
\hline Product & Disintegration Test $(p$ value $)$ & Rupture Test ( $p$ value $)$ \\
\hline Seven Seas & $<0.001$ & 0.030 \\
\hline Higher Nature & $<0.001$ & 0.010 \\
\hline Quest & 0.468 & 0.017 \\
\hline MyDawa & 0.001 & $<.196$ \\
\hline Mega & $<0.001$ & $<0.001$ \\
\hline
\end{tabular}

acidic medium compared to water, except for the Quest capsules. All products exhibited significantly shorter rupture test times in the acidic medium compared to water, except for the Mydawa capsules. The USP requires that all capsules rupture within 15 minutes (9). The mean rupture test values for each product evaluated were less than 15 minutes, but the Mydawa product had one capsule out of the six units tested exceed this time both in water and $0.1 \mathrm{~N} \mathrm{HCl}$.

The results of the Games-Howell multiple comparison tests are shown in Table 2. For disintegration, the Seven Seas product was the fastest (4-5 minutes), and Mydawa was the slowest (20-25 minutes). The Seven Seas capsules were also non-gelatin-based with a shell comprised of modified maize starch, glycerol, carrageenan, water, and sodium carbonate. The rank for disintegration times in water was Seven Seas < Higher Nature < Mega < Quest $<$ Mydawa. In $0.1 \mathrm{~N} \mathrm{HCl}$, the rank for disintegration times was Seven Seas $<$ Higher Nature $=$ Mega $<$ Quest $<$ Mydawa.

For the rupture test, the Mega capsules were the fastest, despite having the largest total capsule weight (1393 $\mathrm{mg})$. Interestingly, the Mega product showed the least variability in both disintegration and rupture tests times, 
with standard deviations that did not exceed 10 seconds in both media. As for disintegration, the Mydawa product had the longest rupture test times in both media. The rank for rupture test times in water were Seven Seas = Mega < Higher Nature = Quest $<$ Mydawa. In $0.1 \mathrm{~N} \mathrm{HCl}$, the order was Mega $<$ Seven Seas $<$ Higher Nature $=$ Quest $<$ Mydawa.

\section{DISCUSSION}

Almukainzi et al. compared the USP disintegration and rupture tests using six soft shell capsule products (nonomega 3) (7). The type of capsule shell material was not specifically stated but was presumably gelatin based on the study's discussion of the results. Their study found no advantage of the rupture test over the disintegration test other than the rupture test generally reached the endpoint more rapidly. The current study also observed that the rupture test times were shorter compared to the disintegration times. It should be noted, however, that the disintegration endpoint in the present study was the time taken for the capsule shell to completely dissolve, whereas Almukainzi et al.'s study reported the endpoint as the time needed to release the entire capsule contents from the shells (7).

In the current work, the relationship between the two tests was further quantified by correlation analysis. Figure 1 shows disintegration and rupture test times for each product in both media graphed in a correlation plot. A significant positive correlation (Pearson's $r=0.85$, $p<0.05$ ) was observed between the two tests. When comparing the tests in water and $0.1 \mathrm{~N} \mathrm{HCl}$ separately, the correlation appears stronger in the acidic medium. The media-specific Pearson's $r$ values were $0.76(p=0.135)$ and 0.94 ( $p=0.018$ ) for water and $0.1 \mathrm{~N} \mathrm{HCl}$, respectively. However, the correlation was limited by the small number of data points $(n=5)$.

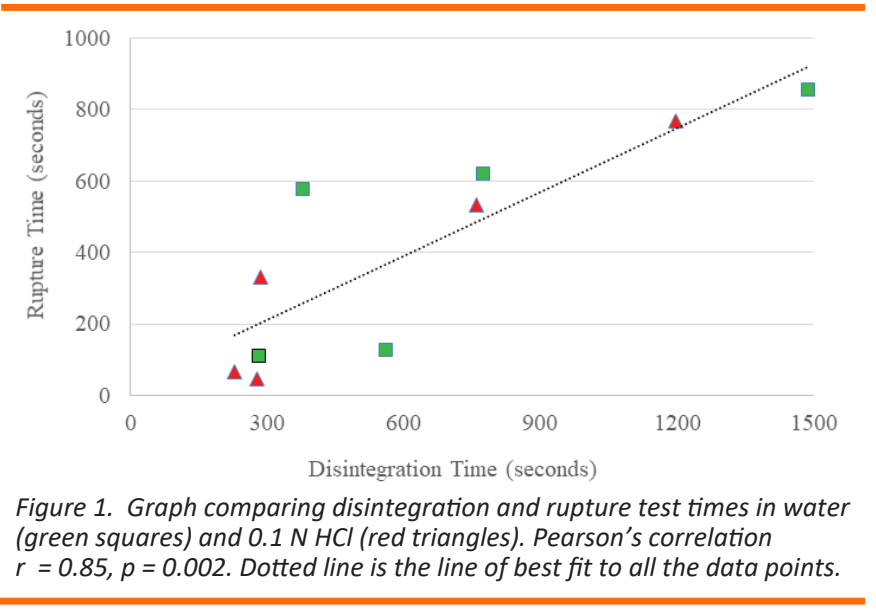

It was observed that the release rate of active ingredient from the capsules was faster in the acidic medium than in water for both the disintegration and rupture tests. Other studies have noted this $\mathrm{pH}$ dependency in gelatin dissolution, although not specifically for capsules $(10,11)$. Gelatin, the primary component of soft gel capsules, is a collagen-derived mixture of water-soluble proteins and comprises amino acids. Amino acids may be charged in aqueous media, with the magnitude of the charge varying with $\mathrm{pH}$. At the isoelectric point (IEP), gelatin will have no net charge. With decreasing $\mathrm{pH}$, protonation of the amino groups increases, making the gelatin more polar. The increased gelatin protonation and polarity increase its aqueous solubility, therefore explaining the faster rate of disintegration in $0.1 \mathrm{~N} \mathrm{HCl}$ compared to water.

Gelatin is a natural material obtained by the acid or base hydrolysis of animal hides, skin, or bones. There are two types of gelatin: type $A$ is produced by acid hydrolysis with an IEP of 6-9, and type B is produced by alkaline hydrolysis with an IEP of around 5 (12-14). Gelatin used for capsule manufacturing may be type $A$, type $B$, or a blend of both types. Consequently, there may be variation in the gelatin IEP from different manufacturers, which may contribute to differences in the solubility of different gelatin-based soft capsule products. Other factors that may contribute to differences in capsule dissolution rates are the gelatin molecular weights, amino acid groups, capsule shell manufacturing process, shell thickness, and the type and amount of added ingredients (e.g., plasticizers) in the shell.

The Seven Seas capsule shells were non-gelatin. From the manufacturer's label, the shell is made of modified starch and carrageenan. Vegetarian capsules avoid the Bovine Spongiform Encephalopathy/Transmissible Spongiform Encephalopathy (BSE/TSE) issues associated with gelatin and are suitable for individuals with religious or personal concerns about consuming animal products. Additionally, they are an option in cases where gelatin cross-linking is a concern. Little information exists in the scientific literature about marketed non-gelatin soft capsules, although a number of patents have been granted. To our knowledge, the current study is the first report on disintegration and rupture testing of a commercially available non-gelatin soft capsule product.

Interestingly, the starch/carrageenan soft capsules also displayed $\mathrm{pH}$-dependent solubility. As the type of modified starch used in the shells was not indicated, it is not possible to make inferences about its dissolution. 
A study by Fauzi et al. on hard capsules prepared from carrageenan cross-linked with maltodextrin reported $\mathrm{pH}$ dependent solubility with faster dissolution observed at lower $\mathrm{pH}$ values (15). Further comparisons are difficult because there are various types of carrageenans, and it is unknown which carrageenan was used in the Seven Seas capsules.

The disintegration and rupture test times for all products fell within what might be considered the immediaterelease range (i.e., $<30$ minutes). Given that the Seven Seas and Mydawa capsules were tested with approximately 6 months of shelf-life remaining, long-term stability did not appear to be an issue for these products.

\section{CONCLUSIONS}

All five products tested disintegrated completely within 30 minutes. Capsule rupture in most cases occurred within 15 minutes. Disintegration and rupture test times were both significantly shorter in $0.1 \mathrm{~N} \mathrm{HCl}$ compared to water. There were significant variations between the release rates of the different soft capsules products, although they were all within the general range for immediaterelease products.

\section{ACKNOWLEDGEMENTS}

The authors would like to acknowledge Mr. Emmanuel Wekesa (University of Nairobi) for assistance with product characterization tests in the Pharmaceutics Laboratory and Ms. Joyce Mang'oi for assistance with rupture tests in the Department of Pharmaceutical Chemistry (University of Nairobi).

\section{CONFLICTS OF INTEREST}

The authors declare no conflicts of interest regarding this work.

\section{REFERENCES}

1. Vascepa Prescribing Information. Amarin Pharma, Inc. https://www.vascepa.com/assets/pdf/Vascepa_ PI.pdf.

2. Dickinson, A.; Blatman, J.; El-Dash, N.; Franco, J. C. Consumer usage and reasons for using dietary supplements: report of a series of surveys. J. Am. Coll. Nutr. 2014, 33, 176-182. DOI: 10.1080/07315724.2013.875423.

3. Albert, B. B.; Derraik, J. G.; Cameron-Smith, D.; Hofman, P. L.; Tumanov, S.; Villas-Boas, S. G.; Garg, M. L.; Cutfield, W. S. Fish oil supplements in New Zealand are highly oxidised and do not meet label content of n-3 PUFA. Sci. Rep. 2015, 5, 7928. DOI: 10.1038/ srep07928.

4. Bannenberg, G.; Mallon, C.; Edwards, H.; Yeadon, D.; Yan, K.; Johnson, H.; Ismail, A. Omega-3 long-chain polyunsaturated fatty acid content and oxidation state of fish oil supplements in New Zealand. Sci. Rep. 2017, 7, 1488. DOI: 10.1038/s41598-017-01470-4.

5. Bannenberg, G.; Rice, H.; Bernasconi, A.; Ferrari, A.; Mallon, C.; Navarrete, L.; Hughes, R.; Igarashi, J.; Persons, K.; Latynski, L.; Phung, A.; Wang, S. Ingredient label claim compliance and oxidative quality of EPA/ DHA omega-3 retail products in the U.S. J. Food Compos. Anal. 2020, 88, 103435. DOI: 10.1016/j. jfca.2020.103435.

6. Scattergood, L.K. Fish oil softgels: A comparison of delayed-release disintegration performance. Tablets and Capsules. Tablets \& Capsules. [Online] 2013. https://tabletscapsules.com/wp-content/uploads/ pdf/tc_20130701_032C.pdf (accessed Mar 8, 2020).

7. Almukainzi, M.; Salehi, M.; Chacra, N. A. B.; Löbenberg, R. Comparison of the rupture and disintegration tests for soft-shell capsules. Dissolut. Technol. 2011, 18, 2125. DOI: 10.14227/DT180111P21.

8. Bachour, G.; Bou-Chacra, N. A.; Löbenberg, R. BouChacra, Nádia.; Löbenberg, Raimar. Evaluation of the rupture test for stability studies of soft-shell capsules. Dissolut. Technol. 2017, 24, 16-19. DOI: 10.14227/ DT240217P16.

9. <2040> Disintegration and Dissolution of Dietary Supplements. In The United States Pharmacopeia and National Formular USP 42-NF 37; The United States Pharmacopeial Convention, Inc.: Rockville, MD, 2019.

10. Chiwele, I.; Jones, B. E.; Podczeck, F. The shell dissolution of various empty hard capsules. Chem. Pharm. Bull. (Tokyo). 2000, 48, 95-96. DOI: 10.1248/ cpb.48.951.

11. Gray, V. A.; Cole, E.; Riva Toma, J. M. D.; Ghidorsi, L.; Guo, J.-H.; Han, J.-H.; Han, F.; Hosty, C. T.; Kochling, J. D.; Kraemer, J.;Langdon, T.; Leinbach, S. R.; Martin, G. P.; Meyerhoffer, S. M.;Moreton, R. C.; Raghavan, K. S.; Shneyvas, E.; Suggett, J. A.;Tindal, S.; Vadathala, M.; Wang, H.; Anand, O.; Gao, Z.; Shah, R.; Xia, L.; Fotso, J.; Hussain, M. A.; Schmidt, V. N.; Ghosh, T.;Davydova, N.; Brown, W. E.; Fringer, J. M.; Stippler, E. S.; Eranui,T.; Marques, M. R. C. Use of enzymes in the dissolution testing of gelatin capsules and gelatin-coated tabletsrevisions to Dissolution $<711>$ and Disintegration and Dissolution of Dietary Supplements $<2040\rangle$. Dissolut. Technol. 2014, 21, 6-19. DOI: 10.14227/DT210414P6.

12. Singh, S.; Rao, K. V.; Venugopal, K.; Manikandan, R. Alteration in dissolution characteristic of gelatin 
containing formulations: a review of the problem, test methods, and solutions. Pharm. Technol. 2002, 26, 36-58.

13. Podczeck, F. Gelatin. In Handbook of Pharmaceutical Excipients, 6th ed. Rowe, R. C., Sheskey, P. J., Quinn, M. E., Eds. American Pharmaceutical Association and the Pharmaceutical Press: Washington DC, London, 2009; pp 278-281.

14. Kanwate, B. W.; Kudre, T. G. Effect of various acids on physicochemical and functional characteristics of gelatin from swim bladder of rohu (Labeo rohita). J. Food. Sci. Technol. 2017, 54, 2540-2450. DOI: 10.1007/ s13197-017-2699-0.

15. Fauzi, M. A. R. D.; Pudjiastuti, P.; Hendradi, E.; Widodo, R. T.; Amin, M. C. I. M. Characterization, disintegration, and dissolution analyses of carrageenan-based hard-shell capsules cross-linked with maltodextrin as a potential alternative drug delivery system. Int. J. Polymer Sci. [Online] 2020, 2020, 3565931. DOI: $10.1155 / 2020 / 3565931$. 